\title{
SENSORY AND BACTERIOLOGICAL EVALUATION OF SOLD CHILLED DUCK AND QUAIL CARCASSES IN MARKETS
}

\author{
EL-DOSOKY, H.F.A. ${ }^{1}$; NASHWA, M. ZAKI ${ }^{1}$ and RAMADAN, A.H. ${ }^{2}$ \\ ${ }^{1}$ Food Hygiene Dept. Mansoura Provential Lab, Animal Health Research Institute \\ ${ }^{2}$ Microbiololgy Dept. Mansoura Provential Lab, Animal Health Research Institute
}

Received: 30 September 2018; Accepted: 30 October 2018

\begin{abstract}
Chilled poultry carcasses are usually subjected to the bacterial contamination during evisceration, preparation and handling. Some of these bacteria are harmful to consumers causing toxicity or infective agents. Hence, this study was done on some chilled duck and quail carcasses collected separately from different supermarkets at Mansoura city and sent to the laboratory for determination of the sensory characters and counts of aerobic plate count (APC), in addition to the prevalence rate of E. coli, Staph. aureus, Salmonella sp. and Listeria

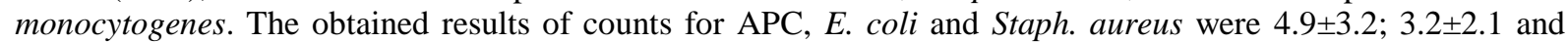
2.7 $\pm 1.6 \log _{10} \mathrm{cfu} / \mathrm{g}$ for chilled duck carcasses and $4.7 \pm 3.6 ; 3.0 \pm 2.3$ and $2.8 \pm 1.4 \log _{10} \mathrm{cfu} / \mathrm{g}$ for chilled quail carcasses respectively. While, the prevalence rate of E. coli, Staph. aureus, Salmonella sp. and L. monocytogenes were 20\%; 22\%; 6\% and $18 \%$ in chilled duck carcasses and 24\%; $18 \%$; $0 \%$ and $16 \%$ for chilled quail carcasses respectively. Serologically the isolated $E$. coli serotypes were O6, O55, O44 and O127 in chilled duck carcasses and O6; O44 and $\mathrm{O} 78$ in chilled quail carcasses and the isolated strains of Salmonella were Salmonella enteritidis and Salmonella anatum in chilled duck carcasses. By PCR the examined isolates of E.coli contained stxl and stx 2 in chilled duck and quail carcasses. While, the examined Staph. aureus by PCR contained the enterotoxigenic strains A, E, C, D enterotoxins in chilled duck carcasses and A, C, D enterotoxigenic strains in chilled quail carcasses. The hygienic importance of isolated bacteria and methods of minimizing its incidence were discussed.
\end{abstract}

Key words: Sensory character; Bacteria; duck; quail carcasses.

\section{INTRODUCTION}

Poultry meat constitutes a substantial portion of human diet. In fact, the world average annual consumption of poultry has increased steadily and now exceeds beef, Because of this high level of consumption, the microbiological quality of poultry purchased in retail markets is of concern for suppliers, consumers and public health officials worldwide so, the bacterial contamination of fresh poultry carcasses has important implications for food safety and product shelf life (FAO, 2011).

Duck and quail meat are an excellent sources of animal-derived high quality proteins. marketed through many supermarkets and its consumers have greatly increased.

Chilled duck and quail carcasses often contaminated with food spoilage and pathogenic microorganisms

Corresponding author: EL-DOSOKY, H.F.A.

E-mail address: rafat552008@yahoo.com

Present address: Food Hygiene Dept. Mansoura Provential Lab, Animal Health Research Institute during slaughtering and processing that decreases its quality and constitutes a public health hazards. Quail meat is a sweet and delicate white game meat with extremely low skin fat and low cholesterol value. Also, it is rich in a wide range of vitamins and minerals including vitamin B6, niacin, thiamin, pantothenic acid and riboflavin, folate and vitamin $\mathrm{E}$ and K. It is therefore recommended for people with high cholesterol levels and those who want to maintain a low level of cholesterol, (Michael, 2014).

Darwish et al. (2015) stated that E. coli was one of the foodborne pathogens associated with several cases of human sickness. E. coli could be isolated from the examined duck meat. Despite the high value of poultry meat, there is no accurate control and inspection on poultry carcasses. Therefore, possibility for transmission of some bacteria such as E. coli, which is one of the main causes of food poisoning. Hence, carcass contamination during slaughtering and processing is a major risk for subsequent foodborne infections in human.

The most dominant pathogens involved were $E$. coli O157, Staph. aureus and L. monocytogenes (Chapman et al., 1997 and Abbasi et al., 2012) and 
Tamarapu et al. (2001) mentioned that Staph. aureus considered as one of the most important Staphylococci species and the third worldwide cause of foodborne illnesses in addition to Freitas et al. (2013) who stated that Salmonella spp. was present in the examined quail carcasses in three evaluated flocks and in the scalding water of one flock. Recently, Kanwal et al. (2015) detect the incidence of $E$. coli and Salmonella through conventional culture method by $82.5 \%$ and $66.6 \%$ and by multiplex PCR $90 \%$ and $82 \%$ respectively in quail meat.

Therefore the present study was designed to determine the sensory quality and the prevalence of some bacteria having hygienic importance that may found in sold chilled duck and quail carcasses.

\section{MATERIALS AND METHODS}

1- Collection of samples: One hundred random chilled duck and quail carcasses samples (50 samples each) were collected separately from different supermarkets at Mansoura city and sent to the laboratory in icebox for examination without delay then, subjected to the following:

2- Sensory examination: Experts in sensory evaluation to evaluate chilled duck and quail carcasses where changes in appearance, odor and texture were recorded and freshness quality scheme was developed according to Costell (2002) and Botta (1995) as follows six trained persons 30-60 years of age made assessments and the sum of points for each sample was transformed to a percentage of maximum demerit points and was expressed as the demerit score.

3- Determination of $\mathbf{p H}$ value: It was carried out according to Pearson (1984).

4- Preparation of the samples for Bacteriological examination according to (APHA 2001): Upon reciept to the laboratory $25 \mathrm{~g}$ from each of the examined carcass (skin and muscles) were homogenized with $225 \mathrm{ml} 0.1 \%$ peptone water in a stomacher for 3 minutes at $3000 \mathrm{rpm}$ and filtered through a sterile cheese cloth filter, followed by ten fold six serial dilutions in $0.1 \%$ peptone water to determine:

A- Aerobic plate count according to APHA (2001).

B- Total count of E. coli: E. coli was detected by using sorbitol MacConkey agar medium (Oxoid, England). The isolated $E$. coli were analyzed biochemically and serologically according to Forbes et al. (2002).

C- Isolation of Staph. aureus according to FDA (2002) using Baird-Parker agar plates, incubated at $35^{\circ} \mathrm{C}$ for $48 \mathrm{hr}$. and the suspected Staph. aureus colonies were picked up, and confirmed by catalase, coagulase, thermostable nuclease and VogesProskauer tests.

D- Isolation of Salmonella according to the technique recommended by (FDA, 2007) on enrichment Rappaport vassiliades broth at $35^{\circ} \mathrm{C}$ for $24 \mathrm{~h}$, platting onto XLD agar at $42^{\circ} \mathrm{C}$ for $24 \mathrm{~h}$. The presumptive colonies were confirmed biochemically and serologically.

E- Isolation of L. monocytogenes according to the technique recommended by USDA; FSIS (1989) and FAO (1992).

F- Detection of virulence genes: the isolated Staph. aureus and E. coli were examined by using PCR for detection of Staph. aureus enterotoxins and E. coli (stx1 and stx2).

\section{1- DNA extraction for isolated Staph. aureus:}

a- DNA extraction from samples was performed using the QIA amp DNA Mini kit (Qiagen, Germany, $\mathrm{GmbH}$ ) with modifications from the manufacturer's recommendations. Briefly, $200 \mu \mathrm{l}$ of the sample suspension was incubated with $10 \mu \mathrm{l}$ of proteinase $\mathrm{K}$ and $200 \mu \mathrm{l}$ of lysis buffer at $56^{\circ} \mathrm{C}$ for $10 \mathrm{~min}$. After incubation, $200 \mu \mathrm{l}$ of $100 \%$ ethanol was added to the lysate. The sample was then washed and centrifuged following the manufacturer's recommendations. Nucleic acid was eluted with $100 \mu$ l of elution buffer provided in the kit.

b- Oligonucleotide Primers used were supplied from Metabion (Germany) are listed in Table 1.

c- For multiplex PCR of enterotoxins, Primers were utilized in a 50- $\mu$ l reaction containing $25 \mu \mathrm{l}$ of Emerald Amp Max PCR Master Mix (Takara, Japan), $1 \mu \mathrm{l}$ of each primer of $20 \mathrm{pmol}$ concentration, $8 \mu \mathrm{l}$ of water, and $7 \mu \mathrm{l}$ of DNA template. The reaction was performed in an Applied biosystem 2720 thermal cycler.

d- Analysis of the PCR Products the products of PCR were separated by electrophoresis on $1.5 \%$ agarose gel (Applichem, Germany, GmbH) in 1x TBE buffer at room temperature using gradients of $5 \mathrm{~V} / \mathrm{cm}$. For gel analysis, $30 \mu \mathrm{l}$ of the multiplex PCR products were loaded in each gel slot. Gelpilot 100 bp DNA ladder (Qiagen, Germany, $\mathrm{GmbH}$ ) was used to determine the fragment sizes. The gel was photographed by a gel documentation system (Alpha Innotech, Biometra) and the data was analyzed through computer software.

\section{2- DNA extraction for isolated $E$. coli:}

a- DNA extraction from samples was performed using the QIA amp DNA Mini kit (Qiagen, Germany, $\mathrm{GmbH}$ ) with modifications from the manufacturer's recommendations. Briefly, $200 \mu \mathrm{l}$ of the sample suspension was incubated with $10 \mu$ l of proteinase $\mathrm{K}$ and $200 \mu \mathrm{l}$ of lysis buffer at $56^{\circ} \mathrm{C}$ for $10 \mathrm{~min}$. After 
incubation, $200 \mu \mathrm{l}$ of $100 \%$ ethanol was added to the lysate. The sample was then washed and centrifuged following the manufacturer's recommendations. Nucleic acid was eluted with $100 \mu \mathrm{l}$ of elution buffer provided in the kit.

b- Oligonucleotide Primers used were supplied from Metabion (Germany) are listed in Table 1.

c- PCR amplification for stx1, stx2 duplex PCR, primers were utilized in a 50- $\mu 1$ reaction containing $25 \mu \mathrm{l}$ of Emerald Amp Max PCR Master Mix (Takara, Japan), $1 \mu$ l of each primer of 20 pmol concentration, $13 \mu \mathrm{l}$ of water, and $8 \mu \mathrm{l}$ of DNA template. The reaction was performed in an Applied biosystem 2720 thermal cycler.

d- Analysis of the PCR Products The products of PCR were separated by electrophoresis on $1.5 \%$ agarose gel (Applichem, Germany, GmbH) in $1 \mathrm{x}$ TBE buffer at room temperature using gradients of $5 \mathrm{~V} / \mathrm{cm}$. For gel analysis, $20 \mu \mathrm{l}$ of the uniplex PCR products and $30 \mu \mathrm{l}$ of the duplex PCR products were loaded in each gel slot. Generuler 100 bp DNA ladder (Fermentas, sigma) was used to determine the fragment sizes. The gel was photographed by a gel documentation system (Alpha Innotech, Biometra) and the data was analyzed through computer software.

Table 1: Primers sequences, target genes, amplicon sizes and cycling conditions for Staph. aureus, E. coli used in multiplex PCR.

\begin{tabular}{|c|c|c|c|c|c|c|c|c|c|}
\hline \multirow[b]{2}{*}{ organism } & \multirow[b]{2}{*}{$\begin{array}{r}\text { Target } \\
\text { gene }\end{array}$} & \multirow[b]{2}{*}{$\begin{array}{c}\text { Primers } \\
\text { sequences }\end{array}$} & \multirow{2}{*}{$\begin{array}{l}\text { Amplified } \\
\text { segment } \\
\text { (bp) }\end{array}$} & \multirow[b]{2}{*}{$\begin{array}{c}\text { Primary } \\
\text { denaturation }\end{array}$} & \multicolumn{3}{|c|}{ Amplification (35 cycles) } & \multirow[b]{2}{*}{$\begin{array}{c}\text { Final } \\
\text { extension }\end{array}$} & \multirow[b]{2}{*}{ Reference } \\
\hline & & & & & $\begin{array}{c}\text { Secondary } \\
\text { denaturation }\end{array}$ & Annealing & Extension & & \\
\hline \multirow{11}{*}{$\begin{array}{l}\text { Staph. } \\
\text { aureus }\end{array}$} & Sea & GGTTATCAA & 102 & $94^{\circ} \mathrm{C}$ & $94^{\circ} \mathrm{C}$ & $50^{\circ} \mathrm{C}$ & $72^{\circ} \mathrm{C}$ & $72^{\circ} \mathrm{C}$ & Mehrotra \\
\hline & & $\begin{array}{c}\text { TGTGCGGGT } \\
\text { GG }\end{array}$ & & $5 \mathrm{~min}$. & 30 sec. & $40 \mathrm{sec}$. & $40 \mathrm{sec}$. & $10 \mathrm{~min}$. & $\begin{array}{l}\text { et al., } \\
2000\end{array}$ \\
\hline & . & $\begin{array}{c}\text { CGGCACTTT } \\
\text { TTTCTCTTCG } \\
\text { G } \\
\end{array}$ & & & & & & & \\
\hline & $\mathrm{Seb}$ & $\begin{array}{c}\text { GTATGGTGG } \\
\text { TGTAACTGA } \\
\text { GC } \\
\end{array}$ & 164 & & & & & & \\
\hline & . & $\begin{array}{c}\text { CCAAATAGT } \\
\text { GACGAGTTA } \\
\text { GG } \\
\end{array}$ & & & & & & & \\
\hline & $\mathrm{Sec}$ & $\begin{array}{c}\text { AGATGAAGT } \\
\text { AGTTGATGT } \\
\text { GTATGG } \\
\end{array}$ & 451 & & & & & & \\
\hline & & $\begin{array}{c}\text { CACACTTTT } \\
\text { AGAATCAAC } \\
\text { CG } \\
\end{array}$ & & & & & & & \\
\hline & Sed & $\begin{array}{c}\text { CCAATAATA } \\
\text { GGAGAAAAT } \\
\text { AAAAG } \\
\end{array}$ & 278 & & & & & & \\
\hline & & $\begin{array}{c}\text { ATTGGTATT } \\
\text { TTTTTTCGTT } \\
\mathrm{C} \\
\end{array}$ & & & & & & & \\
\hline & See & $\begin{array}{c}\text { AGGTTTTTT } \\
\text { CACAGGTCA } \\
\text { TCC } \\
\end{array}$ & 209 & & & & & & \\
\hline & & $\begin{array}{c}\text { CTTTTTTTTC } \\
\text { TTCGGTCAA } \\
\text { TC } \\
\end{array}$ & & & & & & & \\
\hline \multirow[t]{5}{*}{ E. coli } & stx1 & ACACTGGAT & 614 & $94^{\circ} \mathrm{C}$ & $94^{\circ} \mathrm{C}$ & $58^{\circ} \mathrm{C}$ & $72^{\circ} \mathrm{C}$ & $72^{\circ} \mathrm{C}$ & Dipineto \\
\hline & & $\begin{array}{c}\text { GATCTCAGT } \\
\text { GG } \\
\end{array}$ & & $5 \mathrm{~min}$. & $30 \mathrm{sec}$. & $40 \mathrm{sec}$. & $45 \mathrm{sec}$. & $10 \mathrm{~min}$ & $\begin{array}{l}\text { et al., } \\
2006\end{array}$ \\
\hline & & $\begin{array}{c}\text { CTGAATCCC } \\
\text { CCTCCATTA } \\
\text { TG } \\
\end{array}$ & & & & & & & \\
\hline & stx2 & $\begin{array}{c}\text { CCATGACAA } \\
\text { CGGACAGCA } \\
\text { GTT } \\
\end{array}$ & 779 & & & & & & \\
\hline & & $\begin{array}{c}\text { CCTGTCAACTG } \\
\text { AG } \\
\text { CAGCACTTTG } \\
\end{array}$ & & & & & & & \\
\hline
\end{tabular}


Statistical analysis:

The results are expressed as $\log$ mean \pm Standard Error (SE). Data were statistically analyzed using statistical analysis systems.

\section{RESULTS}

Table 2: Sensory quality evaluation of duck (group 1) and quail (group 2) carcasses according to Costell (2002) and Botta (1995).

\begin{tabular}{|c|c|c|}
\hline parameter & characteristic & demerit points \\
\hline \multirow{3}{*}{ Color } & Characteristic meat color & 0 \\
\hline & opaque & 1 \\
\hline & yellowish & 2 \\
\hline \multirow{3}{*}{ Odor (fresh) } & Normal & 0 \\
\hline & Neutral & 1 \\
\hline & Trace off odor & 2 \\
\hline \multirow{3}{*}{ Odor (boiled) } & Normal & 0 \\
\hline & Neutral & 1 \\
\hline & Abnormal urine & 2 \\
\hline \multirow{3}{*}{ Flesh texture } & Firm & 0 \\
\hline & Slightly soft & 1 \\
\hline & Soft & 2 \\
\hline \multirow{3}{*}{ Wetness } & Normal & 0 \\
\hline & Slightly dry or slightly wet & 1 \\
\hline & Moderatly dry or moderatly wet & 2 \\
\hline \multirow{3}{*}{$\begin{array}{l}\text { Contamination (feather, feces, } \\
\text { blood patches) }\end{array}$} & None & 0 \\
\hline & Slight & 1 \\
\hline & Moderate & 2 \\
\hline \multirow{3}{*}{ Fat appearance } & White & 0 \\
\hline & Opaque & 1 \\
\hline & Yellowish & 2 \\
\hline \multirow{3}{*}{ Rancidity (odor) } & Absent & 0 \\
\hline & Slight & 1 \\
\hline & Moderate & 2 \\
\hline \multirow{3}{*}{ Package } & Normal & 0 \\
\hline & Defective & 1 \\
\hline & broken & 2 \\
\hline \multicolumn{2}{|c|}{ Maximum demerit points for duck and quail carcasses (group1\&2) } & $17 \& 19$ \\
\hline
\end{tabular}

Table 3: Sensory and $\mathrm{pH}$ evaluation of the examined duck and quail carcasses

\begin{tabular}{ccc} 
Groups & $\begin{array}{c}\text { Demerit score } \\
(\%)\end{array}$ & $\mathrm{pH}$ \\
\hline Group (1) duck carcasses & $9.7 \pm 2.8$ & $5.8 \pm 0.2$ \\
\hline Group (2) quail carcasses & $15.4 \pm 2.05$ & $5.9 \pm 0.2$ \\
\hline
\end{tabular}

Demerit score $\%=$ total Demerit points transformed to a mean \pm SE percentage of maximum demerit points attainable.

Table 4: Microbial mean counts of the Examined Duck and Quail Carcasses expressed as $\log$ mean \pm SE $(n=50$ for each).

\begin{tabular}{ccccccc}
\hline & \multicolumn{3}{c}{ Duck carcasses } & \multicolumn{2}{c}{ Quail carcasses } \\
\cline { 2 - 6 } Isolated organisms & APC & E. coli & $\begin{array}{l}\text { Staph. } \\
\text { aureus }\end{array}$ & APC & E. coli & Staph. aureus \\
\hline Bacterial count & $4.9 \pm 3.2$ & $3.2 \pm 2.1$ & $2.7 \pm 1.6$ & $4.7 \pm 3.6$ & $3.0 \pm 2.3$ & $2.8 \pm 1.4$ \\
\hline
\end{tabular}


Table 5: Prevalence of the Isolated Bacteria from Examined Duck and Quail Carcasses ( $\mathrm{n}=50$ for each).

\begin{tabular}{ccccccccc} 
carcasses type & \multicolumn{4}{c}{ Duck carcasses } & \multicolumn{2}{c}{ Quail carcasses } \\
\hline Isolated organisms & E. coli & $\begin{array}{c}\text { Staph. } \\
\text { aureus }\end{array}$ & Salmonella & $\begin{array}{c}\text { L. mono } \\
\text { cytogenes }\end{array}$ & E. coli & $\begin{array}{c}\text { Staph. } \\
\text { aureus }\end{array}$ & Salmonella & $\begin{array}{c}\text { L. mono } \\
\text { cytogenes }\end{array}$ \\
\hline Positive no & 10 & 11 & 3 & 9 & 12 & 9 & ND & 8 \\
\hline Prevalence\% & 20 & 22 & 6 & 18 & 24 & 18 & - & 16 \\
\hline
\end{tabular}

NB: $n=50$ means number of examined carcasses from duck or quail carcasses; $\mathrm{ND}=$ not detected

$\%=$ according to the No of examined carcass samples.

Table 6: Serological identification of isolated E. coli and Salmonella in the examined positive duck and quail carcasses.

\begin{tabular}{|c|c|c|c|c|c|c|c|}
\hline \multirow{3}{*}{ Serotypes of $E$. coli } & \multirow{3}{*}{ No } & \multirow{3}{*}{$\begin{array}{c}\text { duck } \\
\text { carcasses }\end{array}$} & \multirow{3}{*}{$\begin{array}{c}\text { quail } \\
\text { carcasses }\end{array}$} & \multicolumn{4}{|c|}{$\begin{array}{l}\text { Identified strains of isolated } \\
\text { Salmonella in Duck carcasses }\end{array}$} \\
\hline & & & & \multirow{2}{*}{$\begin{array}{c}\text { isolated } \\
\text { Salmonella }\end{array}$} & \multirow{2}{*}{ No } & \multicolumn{2}{|c|}{ Antigenic structure } \\
\hline & & & & & & $\mathrm{O}$ & $\mathrm{H}$ \\
\hline \multirow{2}{*}{ O44 } & \multirow{2}{*}{3} & \multirow{2}{*}{2} & \multirow{2}{*}{1} & Salmonella & \multirow{2}{*}{2} & 1,9 & $\mathrm{~g}, \mathrm{~m}:$ \\
\hline & & & & enteritidis & &, 12 & 1,7 \\
\hline \multirow{2}{*}{ O6 } & \multirow{2}{*}{5} & \multirow{2}{*}{3} & \multirow{2}{*}{2} & Salmonella & \multirow{2}{*}{1} & $3,10,15$ & $\mathrm{e}, \mathrm{h}:$ \\
\hline & & & & anatum & & 3,4 & 1,6 \\
\hline O55 & 2 & 2 & - & & & & \\
\hline $\mathrm{O} 78$ & 3 & - & 3 & & & & \\
\hline $\mathrm{O} 127$ & 4 & 4 & - & & & & \\
\hline
\end{tabular}

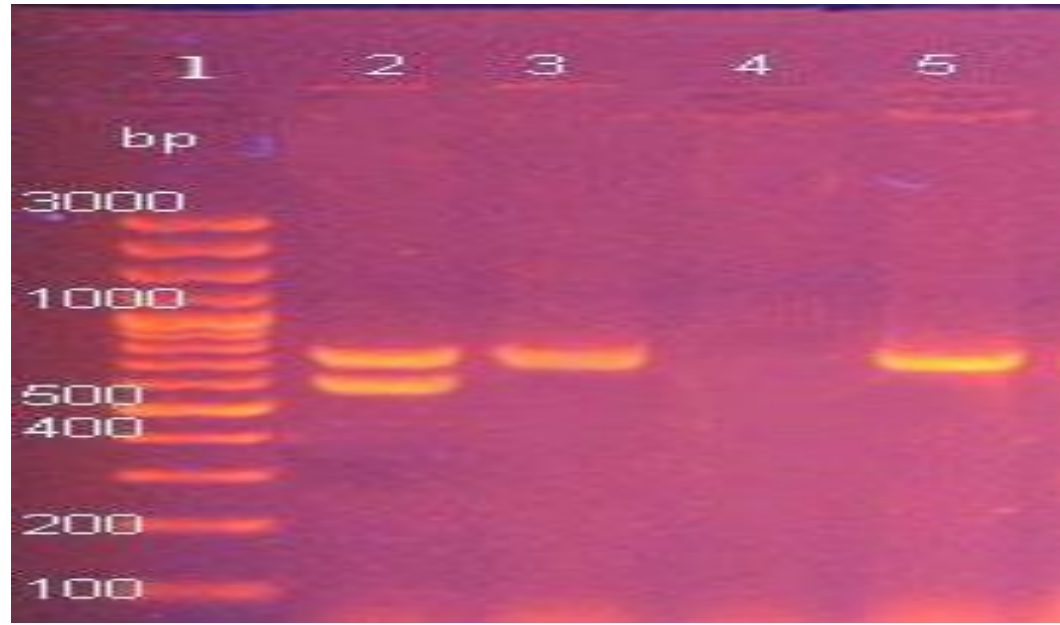

Fig. (1): Agarose gel electrophoresis of E. coli PCR products isolated from chilled duck carcass samples using stxl and stx 2 primers.

Lane "1": 100 bp DNA ladder

Lane "2 ": positive amplification of $614 \mathrm{bp}$ for stx1 gene and $779 \mathrm{bp}$ for stx2.

Lane "3": positive amplification of 779 bp for stx2.

Lane "4": negative amplification for stx1 and stx2 genes.

Lane "5": positive amplification of $779 \mathrm{bp}$ for stx2.

\section{Multiplex PCR for Staph. aureus enterotoxins genes:}

Total number of 5 isolates from Staph. aureus tested by using multiplex PCR by using sets of primers for enterotoxins (A,B,C,D and E). The results obtained by multiplex PCR showed that the 


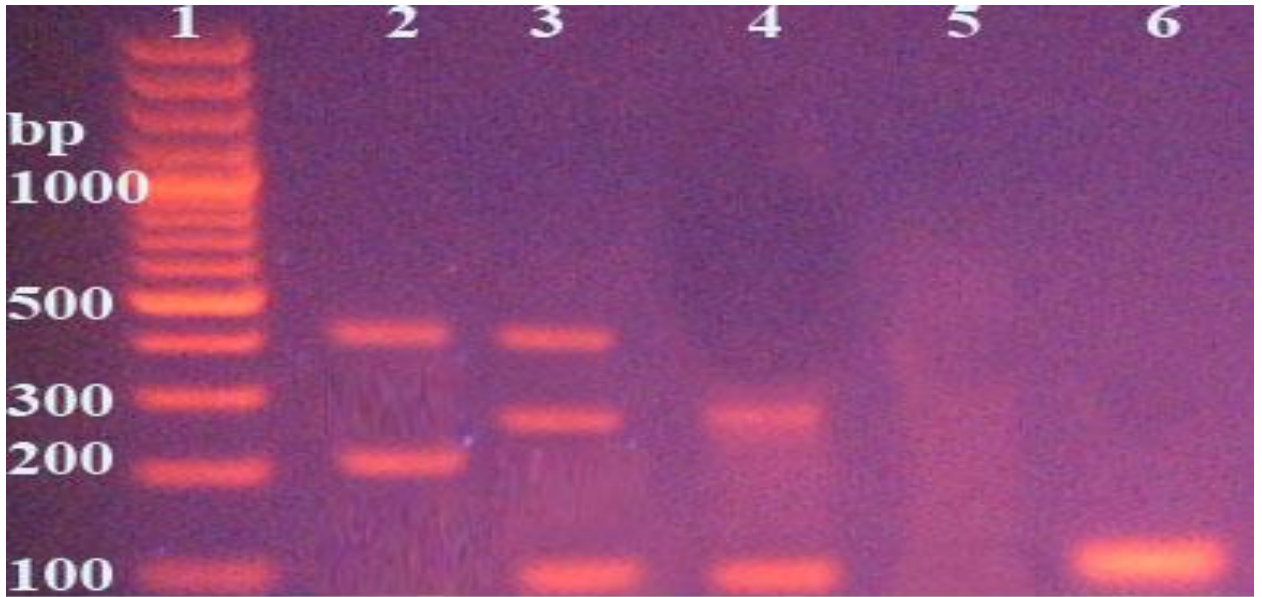

Fig (2): Agarose gel electrophoresis of Staph. aureus PCR products isolated from chilled duck carcass samples using Staph. aureus enterotoxins primers.

Lane "1": 100 bp DNA ladder

Lane "2 ": positive amplification 209 bp for enterotoxin E and $451 \mathrm{bp}$ for enterotoxin C

Lane "3": positive amplification of $102 \mathrm{bp}$ for enterotoxin A, $278 \mathrm{bp}$ for enterotoxin D and $451 \mathrm{bp}$ for enterotoxin C

Lane "4": positive amplification of 102 bp for enterotoxin A and 278 bp for enterotoxin D

Lane "5": negative amplification for Staph. aureus enterotoxins

Lane "6": positive amplification of 102 bp for enterotoxin A

\section{DISCUSSION}

\section{Sensory examination of duck and quail carcasses}

Although dressing of each meat species should be regarded as a unique process. Hence, Evaluation of freshness and potential consumer acceptance defined in terms of carcass characteristics such as appearance, color, odor and texture which were one of the principal aims of this study. Therefore, the sensory quality of duck and quail carcasses were determined on the basis of quality grading assessment Costell, (2002) to which demerit points ranging from 0 to 3 (table 2), the lower score the better quality. All the examined carcass samples for sensory quality inspected separately for each and they were within the acceptable limit.

\section{Hydrogen ion concentration ( $\mathrm{pH})$ :}

The variation in $\mathrm{pH}$ could be a factor in declaring the types of microorganisms growing on poultry carcasses (Hulot and Ouhayoun, 1999). Our results recorded in (table 3) revealed that $\mathrm{pH}$ values of examined duck and quail carcass samples were 5.8 \pm 0.2 and $5.9 \pm 0.2$ respectively. These results nearly agree with (El-Shehry, 2012) who stated that $\mathrm{pH}$ of chicken meat were 5.91 and (Youssef, 2013) found poultry meat $\mathrm{pH}$ mean value were $5.64 \pm 0.02$. Higher results were recorded by Afifi, (2000) in poultry meat with value of (6.15). The decrease in $\mathrm{pH}$ value may be attributed to the breakdown of glycogen with the formation of lactic acid and the increase of $\mathrm{pH}$ may be due to the partial proteolysis. Poultry meat with a $\mathrm{pH}$ below 5.8 had a pale color, while meat with higher $\mathrm{pH}$ had dark color and has a great risk on human health. However, the ideal $\mathrm{pH}$ for meat is between 5.8 and 6.3 (Pearson and Gillette, 1996).

The bacterial count of any food article is not indicative about its safety for consumption, yet it was of more importance in judging the hygienic conditions under which it had been produced, handled and stored (Jay, 1997).

The recorded results in (table 4) showed that the mean APC for duck and quail carcasses were 4.9 \pm 3.2 and $4.7 \pm 3.6 \log _{10} \mathrm{cfu} / \mathrm{g}$ respectively with prevalence rate of $100 \%$ in duck and quail carcasses. These results were nearly similar to that reported by (Nyo et al., 2010) where the APC were $4.8 \log _{10} \mathrm{cfu} / \mathrm{g}$ of the examined slaughtered duck carcass samples and (Edris et al., 2011) where they found $9 \times 10^{4} \pm 1.43 \times 10^{4}$ $\mathrm{cfu} / \mathrm{g}$ in Quail meat meanwhile, slightly higher than (Alvarez-Fernandez et al., 2009) who found that the mean aerobic count were $4.01 \pm 0.48 \log _{10} \mathrm{cfu} / \mathrm{g}$ in duck carcasses. The higher bacterial counts of examined carcasses may be due to unsatisfactory sanitation during handling, processing and distribution as well as inadequate chilling which increase the existing organisms as reported by (Thatcher and Clark, 1973). These results were in accordance with the Egyptian Organization for Standardization and Quality Control (EOS) No. 1651 (2005) for APC in chilled poultry meat $\left(<10^{5} \mathrm{cfu} / \mathrm{g}\right)$.

There is no accurate control and inspection on poultry carcasses in the slaughter houses. Therefore, the possibility of some bacterial transmission such as $E$. coli, which is one of the main causes of foodborne 
pathogens associated with several cases of human sickness.

People with low immunity are the prime target of the pathogenic strains of $E$. coli. The main habitat of E.coli is the intestinal tract of human and animal. So its presence indicates fecal contamination. Moreover, many strains of the organism are enteropathogenic and give rise to acute diarrheal hemorrhagic enteritis in adults (Law 2000 \& Akbar and Anal, 2011).

The obtained results in (tables $4 \& 5$ ) showed that the mean value of $E$. coli counts in chilled duck and quail carcasses were $3.2 \pm 2.1$ and $3.0 \pm 2.3 \log _{10} \mathrm{cfu} / \mathrm{g}$ with prevalence rate $20 \%$ and $24 \%$ respectively. Serologically (table 6) the isolated E. coli serotypes were O6, O55, O44 and $\mathrm{O} 127$ in chilled duck carcasses and O6; 044 and $\mathrm{O} 78$ in chilled quail carcasses while, $\mathrm{O} 157: \mathrm{H} 7$ could not be isolated either from duck or quail carcasses. The examined isolates of $E$. coli by PCR (Fig1) contained stx 1 and stx 2 in chilled duck and quail carcass samples.

These results were nearly similar to that recorded by (Edris et al., 2011) who found E. coli count $1.18 \times 10^{4} \pm 4.55 \times 10^{4} \mathrm{cfu} / \mathrm{g}$ in $40 \%$ of the examined quail carcasses and (Fodor, 2007) detect E.coli in $25.3 \%$ of broiler carcass samples, but none was serotype O157:H7 also, (Hamad et al., 2012) could isolate $E$. coli from $18.2 \%$ of the examined quail carcasses in addition to (Kanwal et al., 2015) found $25.6 \%$ of the examined quail carcasses contaminated with $E$. coli while, (Darwish et al., 2015) could isolate E. coli O86, O127, O114, O26 and O78 from the examined duck meat and (Hemmatinezhad et al., 2015) reviewed that $E$. coli in duck and quail meat samples were $32.5 \%$ and $27.77 \%$ and the isolated serotypes were positive for stx1. Also, (Nyo et al., 2010) added that the $E$. coli count were $2.9 \pm 0.16 \log _{10} \mathrm{cfu} / \mathrm{g}$ with presence of E. coli O72, O44, O124, and $\mathrm{O} 82$ in the examined slaughtered duck samples and (Fernandes, et al., 2009) found $E$. coli count $3.7 \pm 0.8 \log _{10} \mathrm{cfu} / \mathrm{g}$ in $19 \%$ of the examined duck carcasses.

Presence of E. coli may be attributed to poor carcass sanitation caused by direct or indirect fecal contamination either from human or animal sources and mishandling ICMSF, (1978). The positive results were unacceptable according to the EOS No. 1651 (2005) for E. coli in chilled poultry meat.

Staph. aureus commonly causes gastroenteritis resulting from consumption of contaminated food in which enterotoxigenic staphylococci have grown and produced toxins. As these toxins are excreted from the organism, they are referred to as exotoxins. Staphylococcal enterotoxins are considered a potential biological threat because of their stability at $100^{\circ} \mathrm{C}$ for 1 hour (Rabello et al., 2007) and (Weronika and Jacek 2014) found that $11.9 \%$ of the isolated Staph. aureus strains were positive for one or more classical SE markers. Also, (Evenson et al., 1988) showed that growth of enterotoxigenic Staph. aureus up to $10^{6}$ or more/g of food enables them to produce a sufficient amount of enterotoxins to cause intoxication. As little as 20ng of SE can induce nausea, violent vomiting, abdominal cramps, and diarrhea between 1 to $8 \mathrm{~h}$ after food consumption. Presence of Staph. aureus in a food indicates contamination due to food handlers and inadequately cleaned equipments. Staph. aureus recorded in cases of severe diarrhea and vomiting as well as cases of food poisoning enteritis among consumers (Davis and Board, 1998).

The data found in (tables 4\&5) showed that the count of Staph. aureus present in chilled duck and quail carcasses were $2.7 \pm 1.6$ and $2.8 \pm 1.4 \log _{10} \mathrm{cfu} / \mathrm{g}$ with prevalence rate $22 \%$ and $18 \%$ respectively in the examined samples. The examined Staph. aureus by PCR (Fig 2) contained the enterotoxigenic strains A, $\mathrm{E}, \mathrm{C}, \mathrm{D}$ enterotoxins in the examined chilled duck carcass samples and A, C, D enterotoxigenic strains were found in the examined chilled quail carcass samples. These results lower than that recorded by (Edris et al., 2011) who isolated Staph. aureus from $40 \%$ of the examined quail carcass samples and nearly similar to (El-Dengawy and Nassar, 2001) where they found that the mean values of Staph. aureus were $1 \times 10^{3} \mathrm{cfu} / \mathrm{g}$ in quails meat and (Hamad et al., 2012) who examined quail carcasses and could isolate Staph. aureus from $16.3 \%$ of the examined samples. While, (Khalifa and Nassar, 2001) found the mean values of Staph. aureus count were $3.1 \log _{10}$ $\mathrm{cfu} / \mathrm{g}$ of pintail breast and thigh duck muscles. Also, (Fodor, 2007) isolate Staph. aureus from 20\% of broiler carcass samples and (Nyo, et al., 2010) found Staph. aureus count were $2.4 \pm 1.2 \log _{10} \mathrm{cfu} / \mathrm{g}$ in the examined slaughtered duck carcass samples, (Fernandes et al., 2009) could isolate Staph. aureus from $24 \%$ of the examined duck carcasses with count of $3.1 \pm 1.4 \log _{10} \mathrm{cfu} / \mathrm{g}$. The positive results were not in accordance with the EOS No. 1651 (2005) for Staph. aureus in chilled poultry meat.

The recorded results of Salmonella (table 5) declared that Salmonella could not be detected in the examined quail carcasses and isolated from $6 \%$ of the examined duck carcass samples. Serologically (table 6) the isolated strains were Salmonella enteritidis and Salmonella anatum. These results were in accordance with Mousa et al. (2016) who failed to isolate Salmonella from the examined frozen quail samples. Moreover, El-Dengawy and Nassar (2001) could not isolate Salmonella from the examined quail carcasses on the other hand Khalifa and Nassar (2001) declared that No Salmonella could be isolated from the examined game duck carcasses while, Fernandes et al. (2009) found Salmonella spp. in $7.69 \%$ of the examined frozen quail carcass samples and Nyo et al. (2010) found Salmonella in $10 \%$ of examined slaughtered duck samples in addition to Reusse et al. 
(1976) declared that Salmonella was present in $10.2 \%$ of frozen duck carcasses when only the skin of the cloaca region was sampled. Also, Hoszowski and Wasyl (2005) found Salmonella in $5.54 \%$ of poultry carcasses. Meanwhile, higher results reported by Fodor, (2007) who isolate Salmonella from $18 \%$ of broiler carcass samples. Recently Szosland-Faltyn et al. (2014) found $40 \%$ of examined duck meat contained Salmonella sp. which may be due to bad sanitation during evisceration, processing and storage.

The positive results of Salmonella sp. were not in agreement with the EOS No. 1651 (2005) for chilled poultry meat.

Listeria monocytogenes was one of the major pathogenic species in both man and animal. These pathogens decrease meat quality and constitutes a public health hazards. Mclauchlin and Jones (1999). The achieved results in (table 5) declared that the prevalence rate of $L$. monocytogenes were detected in $18 \%$ and $16 \%$ of the examined chilled duck and quail carcass samples respectively. These results were nearly achieved by Szosland-Faltyn et al. (2014) where they found L. monocytogenes in $24 \%$ of the examined duck meat samples in addition to Kevenk and Gulel (2016) mentioned that L. monocytogenes were found in $15.6 \%$ of the examined duck carcasses and Vannetten et al. (1998) could isolate $L$. monocytogenes from $19 \%$ of the examined poultry carcasses. Also, Wijendra et al. (2014) found $21 \%$ of the examined quail meat contaminated with $L$. monocytogenes.

The positive results of $L$. monocytogenes were not in agreement with the EOS No. 1651 (2005) for chilled poultry meat.

\section{CONCLUSION}

Hygienic measures should be applied specially antemortem inspection before slaughtering. Instruments used for slaughtering should be periodically cleaned and disinfected. Bleeding of slaughtered carcasses should be through channels in order to minimize aerial contamination. Periodical sanitation of duck and quail slaughter halls, utensils, equipments, chilling rooms and freezing cold stores. All these precautions must be followed to improve the hygienic quality of the retailed carcasses.

\section{REFERENCES}

Abbasi, S.; Momtaz, H.; Rahimi, E.; Momeni, M. and Riahi, M. (2012): Detection and assessment of antimicrobial resistance properties in E. coli O157 isolated from pheasant, partridge, duck and goose meat. Pejouhandeh.17(4):210-214.

Afifi-Jehan, S.A. (2000): Chemical studies on some poultry meat products. M.V.Sci. Thesis, Fac. Vet. Med., Zagazig University.
Akbar, A. and Anal, K.A. (2011): Food safety concerns and food- borne pathogens, Salmonella, E. coli and Campylobacter. FUUAST j. of Biology, 1(1): 5-17.

Alvarez-Fernandez, E.; Cancelo, A.; Diaz-Vega, C.; Capita, R. and Alonso-Calleja, C. (2009): Antimicrobial resistance in $E$. coli isolates from conventionally and organically reared poultry: a comparison of agar disc diffusion and Sensi Test Gram-negative methods. Food Control. 30(1): 227-234.

APHA (American Public Health Association) (2001): Compendium methods for the microbiological examination of food, Wahington, DC.

Botta, J.R. (1995): Evaluation of seafood freshness quality. VCH Publishers, Inc., New York.

Chapman, P.; Siddons, CA.; Cerdan Malo, AT. and Harkin, MA. (1997): A one year study of $E$. coli $\mathrm{O} 157: \mathrm{H7}$ in cattle, sheep, pigs and poultry. Epid. Infec., 119: 245-250.

Costell, E. (2002): A comparison of sensory methods in quality control. Food Quality Preferation. 13:341-353.

Darwish, W.S.; Eldin, W.F.S. and Eldesoky, K.I. (2015): Prevalence, molecular characterization and antibiotic susceptibility of E. coli isolated from duck meat and giblets. J. of Food Safety. 35(3): 410-415.

Davis, A. and Board, R. (1998): The microbiology of meat and poultry. A. textbook, 1st Ed., Edmunds bury Press, Ltd, Edmunds, London.

Edris, A.M.; Shaltout, F.A. and Arab, W.S. (2011): Bacterial Evaluation of Quail Meat Dept, of Food Control, Fac. Vet. Med. (Moshtohor) Zagazig Univ. / Benha branch.

Egyptian Organization for Standardization and Quality Control (EOS) No. 1651 (2005): Bacteriological standardization for chilled poultry. Ministry of industry and technological development, Arab Republic of Egypt (A.R.E.).

El-Dengawy, R.A. and Nassar, A.M. (2001): Investigation on the nutritive value and microbiological quality of wild quail carcasses. Nahrung. 45(1): 50-54.

El-Shehry-Eman, M.A. (2012): Chemical anylsis of chicken meat with relation to its quality. $\mathrm{Ph}$. D. Thesis, Fac. Vet. Med., Benha Univeristy.

Evenson, M.; Hinds, M.; Bernstein, R. and Bergdoll, M. (1988): Estimation of human dose of staphylococcal enterotoxin-A from a large outbreak of staphylococcal food poisoning involving chocolate milk. Int. J. Food Microbiol. 7, 311-316.

Fernandes, E.F.T.S.; Vilela, S.M.O.; Barbosa, D.F.A.; Paulino, A.A.; Faria, E.B. and Mota, R.A. (2009): Contamination for Staphylococcus spp., Salmonella spp., Coliforms total and thermotolerants in commercialized carcasses of quail (Coturnix 
coturnix japonica) in the city of Recife-PE. Medicina Veterinaria (Brasil). 3(2): 9-14.

Fodor, I. (2007): Observation upon the development of a pseudomonosis episode in broiler farm. Lucrari Stiinifice Med Vet, XL: 375-378.

FAO. (2011): Faostat: Food balance sheets. Internet site. http://faostat.fao.org/site/368/ Desktop Default.aspx?PageID $1 / 4368 \#$ ancor Accessed 20.12.11.

FAO (1992): (Food Agricultural Organization) Manual of food quality control. J. Microbiological Analysis of Food and Agriculture Organization of the United Nations, Rome. 4 Rev. Chapter 11, 119 - 129.

FDA, (2002): (Food and Drug Administration) Bacteriological Analytical Manual 9th ed. AOAC, International Arlington, VA, USA.

FDA (2007): BAM. Salmonella. Bacteriological analytical manual, $8^{\text {th }}$ ed., Revision A, 1998. Chapter 5 Authers: Wallace H. Andrews and Thomas Hammack.

Forbes, BA.; Saitm, DF. and Weissfeld, AS. (2002): Bailey and Scott's Diagnostic Microbiology, 11th edition. St. Louis, MO: Mosby. 285-296.

Freitas, Neto, O.C. de; Angela, H.L. da; Soares, N.M.; Guastalli, E.A.L.; Almeida, A.M. de and Berchieri Junior, A. (2013): Salmonella spp. in meat-type quails (Coturnix coturnix coturnix) in the State of Sao Paulo, Brazil. Brazilian J. of Poultry Science. 15(3):277-281.

Hamad, M.A.; Al-Aalim, A.M.; Al-Dabbagh, S.Y.A. and Ali, H.H. (2012): Detection of organ bacterial load in quails. Iraqi J. of Veterinary Sciences. 26(Suppl. 2): 47-51.

Hemmatinezhad, B.; Khamesipour, F.; Mohammadi, M.; Dehkordi, F.S. and Mashak, Z. (2015): Microbiological investigation of Oserogroups, virulence factors and antimicrobial resistance properties of Shiga toxin-producing E. coli isolated from ostrich, turkey, duck and quail meat. J. of Food Safety. 35(4): 491-500.

Hoszowski, A. and Wasyl, D. (2005): Salmonella prevalence and resistance to antibiotics in Poland. Medycyna Weterynaryjna. 61(6): 660663.

Hulot, F. and Ouhayoun, J. (1999): Muscular pH and related traits in poultry; a review -world poultry Sci., 7;15-36.

ICMSF (1978): (International commission on Microbiological specification for foods) Micro-organisms in foods. sampling for microbiological analysis.

Jay, J.M. (1997): Modern food microbiology 4th Ed. Chapman and Hall, international Thomson Publishing, New York.

Kanwal, Amna; Sheikh, A.A.; Masood Rabbani; Tanveer Hussain; Iqra Safdar; Ayesha Tabassum; Asfa Rasool; Javed Muhammad and Mawra, Gohar (2015): Detection of E. coli and Salmonella from retail quail meat through optimized multiplex PCR. Pakistan J. of Agricultural Sciences. 52(3): 809-813.

Kevenk, T.O.; Gulel, G.T. (2016): Prevalence, antimicrobial resistance and serotype distribution of Listeria monocytogenes isolated from chicken, turkey, duck and ostrich carcasses. J. of Food Safety. 36(1): 11-18.

Khalifa, A.H. and Nassar, A.M. (2001): Nutritional and bacteriological properties of some game duck carcasses. Nahrung; 45(4): 286-292.

Law, D. (2000): A review, Virulance factors of E.coli O:157 and other Shiga toxin-producing E. coli. J. Appl. Microbio. 88:729-745.

Mclauchlin, Y. and Jones, D. (1999): Erysiperothrix and listeria. In: Borriello, S.P. Duerden, B.I (Eds.). Toplay, $9^{\text {th }}$ ed. Systematic Bacteriology (2) up date the CD. Rom London, Amold.

Mehrotra, M.; Wang, G. and Johnson, M.W. (2000): Multiplex PCR for detection of genes for Staph. aureus enterotoxin, exfoliative toxins, toxic shock syndrome toxin 1 , and Methicillin resistance. J. of Clinical Microbiology, 38: 1032-1035.

Michael, I. (2014): Benefits about quail meat and egg. Sunday post. On line edition of Nagaland's frist and foremost news daily. Sunday, Appril 27.

Mousa, M.M.; Salem, N.I.E.; Khalifa, A.M.A.; AbdEl-Hady, H.A.M. and El-Gamel, A.M. (2016): Quality assessment of frozen quail in Kafr ElSheikh Governorate. Alexandria J. of Veterinary Sciences. 48: 57-61.

Nyo, N.L.; Hildebrandt, G.; Kleer, J.; Kannika, N.L. (2010): The microbiological quality of slaughtered ducks from a local slaughterhouse in Chiang Mai, Thailand. Globalization of tropical animal diseases and public health concerns. Proceedings of the 13th Association of Institutions for Tropical Veterinary Medicine (AITVM) Conference, Bangkok, Thailand: $39-42$.

Pearson, (1984): "Chemical Analysis of Food"8th Ed., Ronald<s Kirk, Ronald Sawyer, Eagan.

Pearson, A.M. and Gillette, T.A. (1996): Processed meats. 3rd Ed New, York Albany, Bonn, Boston, London.

Rabello, R.F.; Moreira, B.M.; Lopes, R.M.M.; Teixeira, L.M.; Riley, L.W. and Castro, A.C.D. (2007): Multilocus sequence typing of Staph. aureus recovered from cows with mastitis in Brazilian dairy herds. J. Med. Microbiol., 56, 11: 1505-1511.

Reusse, U.; Meyer, A. and Tillack, J. (1976): Detection of Salmonellae in frozen poultry. Archiv fur Lebensmittel hygiene. 27(3): 98100.

Szosland-Faltyn, A.; Bartodziejska, B.; Krolasik, J. and Paziak-Domanska, B. (2014): Occurrence of Campylobacter sp. and Salmonella sp. in Polish duck meat in the presence of other spoilage microbial groups. Acta Scientiarum 
Polonorum - Medicina Veterinaria. 13(1/4): 27-35.

Tamarapu, S.; McKillip, J.L. and Drake, M. (2001): Development of a Multiplex Polymerase Chain Reaction assay for detection and differentiation of Staph. aureus in dairy products. J. Food Prot., 64: 664-668.

Thatcher, F.S. and Clark, T.S. (1973): Microorganisms in Food: Their Significance and methods of enumeration. J. Royal Soc. Promo. Health. Com. Count. 90, (2): 120.

Tront, I.I. and Olburn, P. (1995): Meat from dairy cows: possible microbial hazards and rir-, Sci. Technol. 16 (2): O.S-414.

USDA; FSIS "United State Department of Agriculture; Food Safety Inspection Service" (1989): Method for the isolation and identification of L. monocytogenes from meat and poultry products. Laboratory Communities, No. 57, US Department of Agriculture, Washington, D.C.
Vannetten, P.; Perales, I.; Vandemossdij, K.A.; Curtis, G.D.W. and Moosal, D.A.A. (1998): Liquid and solid selective differential media for the detection and enumeration of $L$. monocytogenes and other listeria species. Int. J. Food Microbiol., 8: 299 - 316.

Wijendra, W.A.S.; Kulathunga, K.A.K.C. and Rathnasinham Ramesh (2014): First report of Listeria monocytogenes serotypes detected from quail meat in Sri Lanka. (Special Issue: Listeriosis and its public health concerns. Advances in Animal and Veterinary Sciences. 2(5S): 11-16. 1: 317-325.

Weronika Korpysa-Dzirb and Jacek Osek (2014): Detection of classical genes and enterotoxins of Staph. aureus isolated from raw milk in the south-east region of Poland. Bull Vet Inst Pulawy 58, 559-561.

Youssef-Fatma, E. (2013): Chemical profile of some frozen poultry meat. ph.D., Thesis (Meat hygiene). Fac. Vet. Med. Benha. Univ.

\section{التقييم الحسى والبكتريولوجي لذبائح البط والسمان والمباعة مبردة فى الاسواق}

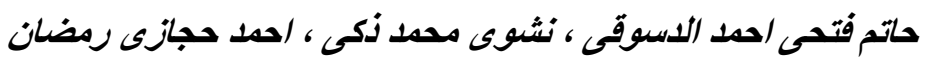

E-mail:rafat552008@yahoo.com

Assiut University web-site: www.aun.edu.eg

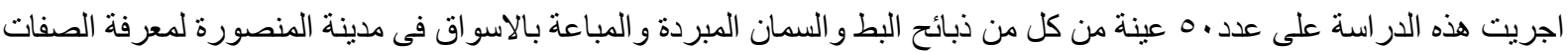

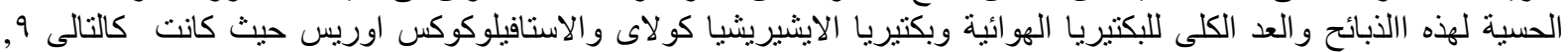

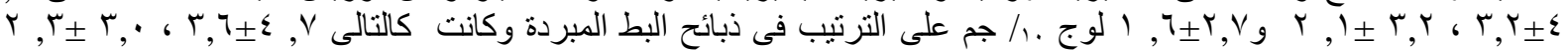

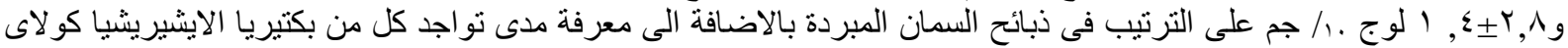

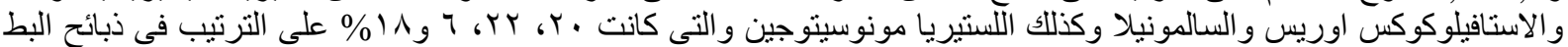

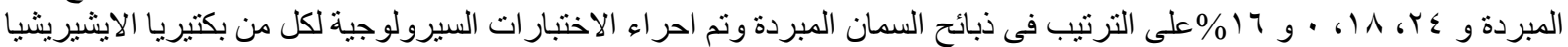

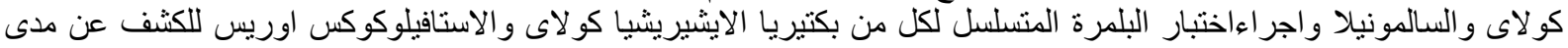

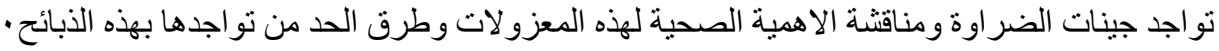

